\title{
Respiratory virus infections and aeroallergens in acute bronchial asthma
}

\author{
K H CARLSEN, I ØRSTAVIK, J LEEGAARD, AND H HØEG \\ Department of Paediatrics and Microbiological Laboratory, Ullevål Hospital, Oslo and Institute of Geology, \\ University of Oslo, Norway
}

SUMmaRY Two hundred and fifty six attacks of acute bronchial asthma occurring in 169 children aged over 2 years were studied during a two year period. More attacks occurred during spring and autumn than at other times of the year. In 73 patients $(29 \%)$ a respiratory virus infection was diagnosed, with the same seasonal variation as the asthmatic attacks. Most of the virus infections were caused by rhinovirus $(45 \%)$ and respiratory syncytial virus $(19 \%)$. There was no significant correlation between asthmatic attacks in patients with birch pollen, grass pollen, or Cladosporium herbarum allergy and counts of the respective pollen or spores in the air. More seasonal attacks occurred in patients with cladosporium allergy than in patients without cladosporium allergy but there was no seasonal variation among birch or grass pollen allergic patients. Information about exposure to animals was obtained in only $12 \%$ of attacks occurring in 121 patients with allergy to animal dander. The single precipitating factor most frequently associated with acute asthma was respiratory virus infection.

Attacks of bronchial asthma may have many causes in both the individual patient and among different patients. Several different factors may precipitate attacks, either separately or working together. ${ }^{1}$ Allergy, respiratory tract infections, and airway irritants such as cigarette smoke are among the most frequently mentioned. To evaluate the role of respiratory virus infections in acute asthma and to assess their importance in relation to other factors such as aeroallergens, a two year prospective study was undertaken among children in Oslo. Epidemiological, clinical, and laboratory findings are presented.

\section{Patients and methods}

Population and patients. Most children in Oslo with diagnosed asthma or allergy, or both, are regularly seen at the Allergy Unit of the Department of Paediatrics, Ullevål Hospital and admissions to hospital caused by these disorders are made to this department. Between January 15, 1981 and January 15,1983 all patients with acute bronchial asthma seen at the allergy unit or admitted to the department of paediatrics were considered for the study. To be included patients had to be (a) above 2 years of age, (b) have been previously diagnosed as asthmatic, and (c) have had at least three previous attacks.
Microbiological studies. Nasopharyngeal secretions were collected on the morning after the patients' admission to hospital or at the time of the outpatient consultation. Secretions were collected during 247 of the 256 attacks included in the study. The specimens were examined by immunofluorescence for respiratory syncytial virus, parainfluenza virus 1 and 3 , influenza virus $A$ and $B$, and adenovirus antigens. The specimens were also inoculated into cell cultures of HeLa and LLC MK2 cells. The LLC MK2 cell cultures were maintained in a medium containing trypsin to enhance their susceptibility to paramyxo- and myxoviruses. ${ }^{2}$ The nasopharyngeal aspirates were examined for rhinovirus by inoculation into Ohio-HeLa cells. ${ }^{3}$ The rhinoviruses were identified by their cytopathic effect, chloroform stability and acid lability as described by Grist et al. ${ }^{4}$

Acute and convalescent sera, usually obtained after an interval of 14 days, were tested by the complement fixation test for antibodies against influenza $\mathrm{A}$ and $\mathrm{B}$; parainfluenza 1, 2, and 3; respiratory syncytial virus; and adeno (group) virus antigens. ${ }^{4}$ Sera were also tested for IgG antibodies against the human coronavirus strain OC 43 in an enzyme linked immunosorbent assay. The antigen was prepared from coronavirus infected Vero cells, and the enzyme linked immunosorbent assay was as described by Voller et al. ${ }^{5}$ Acute and convalescent 
sera were obtained from 199 of the 256 attacks included in the study.

A patient was considered infected by a virus if the virus was identified from the nasopharyngeal secretions or if there was an appreciable difference in antibody titre (at least fourfold) between acute and convalescent sera.

Nasopharyngeal swabs were collected at presentation for routine bacteriological examination according to standard methods. ${ }^{6}$ Identification of Haemophilus influenzae, Streptococcus pneumoniae, and Streptococcus pyogenes was considered to be of potential pathogenic importance.

Allergy diagnosis. All patients included in the study were evaluated by skin prick test, ${ }^{7}$ radioimmunosorbent test (Phadebas-RIST, Phadebas-PRIST), and radioallergosorbent test (Phadebas-RAST). The skin prick test was performed with the following allergens: Dermatophagoides farinae, birch pollen, grass pollen (timothy) (Spectralgen prick, Nyco, Oslo) and Cladosporium herbarum, dog dander, and cat dander (Soluprick, ALK, Copenhagen). At presentation blood samples were taken for IgE determination and eosinophil count. The IgE determination was made by radioimmunosorbent test for the first 9 months of the study and by paper radioimmunosorbent test thereafter. ${ }^{9}$ The radioallergosorbent test was performed with the same allergens as the skin prick test. The skin prick test was evaluated according to the guidelines issued by Aas and Belin. ${ }^{7}$ The radioallergosorbent test was considered positive when at least class 2 was obtained.

The patients were considered atopic by a combined evaluation of the skin prick test and the results of total IgE and specific IgE. To be atopic the patients had to have a positive skin prick test and a positive radioallergosorbent test or raised total IgE (greater than 2 SD for age), or a positive radioallergosorbent test and raised total IgE.

Pollen and spore counts. Pollen registration in Oslo was started in 1975 with a centrally located Hirst pollen and spore trap. Spore counts were started two years later. The pollen and spore registration was made as described by Hirst ${ }^{10}$ so that concentrations could be calculated as daily mean values and as hourly values.

As the most frequent pollen allergies in Norway are birch pollen and grass pollen allergy and the most frequent allergy to moulds is $C$ herbarum allergy, these have been used in the study.

Statistical methods. Statistical analyses were performed using the Wilcoxon-Mann-Whitney rank test for two samples (W-M-W), the Pearson's correlation coefficient $(\mathrm{r})$, the Student's $t$-test, and the $\chi^{2}$ test.

\section{Results}

Epidemiological findings. During the study period 256 attacks of acute bronchial asthma occurred in the 169 patients included in the study. Fig. 1 shows the distribution of the attacks according to the first day of symptoms/two week period. The occurrence of acute asthmatic attacks varied throughout the study period with a pattern of increased frequency during spring and autumn in both years. The greatest number of patients were admitted during the last half of August and throughout September in both years. Few cases occurred during the summer months.

Virological findings. A respiratory virus infection was diagnosed in $73(29 \%)$ of the patients suffering acute asthmatic attacks. Most of the infections were diagnosed by virus isolation or identification by immunofluorescence but in 24 cases the virus infection was detected by antibody titre rise only (respiratory syncytial virus, 8 cases; parainfluenza virus, 6 cases; adenovirus, five cases; influenza A virus, one case; coronavirus, four cases). Fig. 1 shows the distribution of acute asthma with respiratory virus infection/two week period compared with all acute attacks in the study. A positive correlation was found between acute asthmatic attacks with

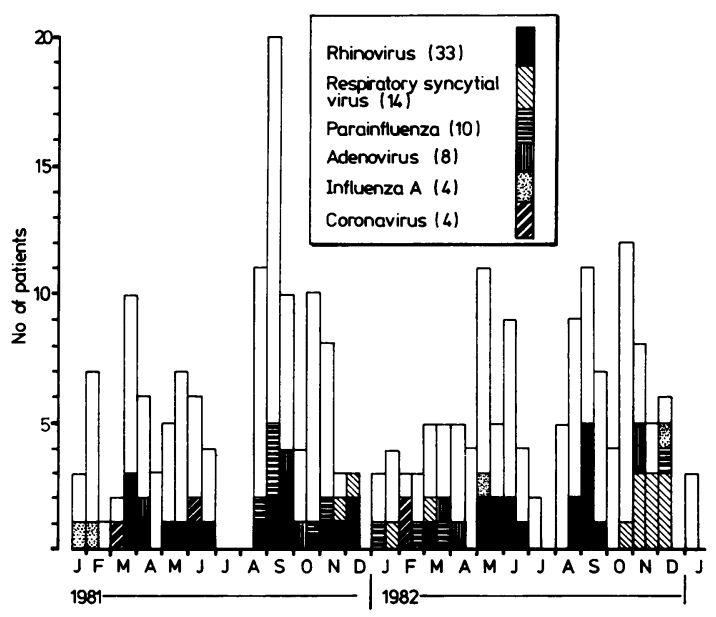

Fig. 1 Acute asthmatic attacks among 256 patients/two week period between 1981 and 1983. Identified respiratory virus infections $(n=73)$ are shown. 
and without virus infection/two week period $(r=0.53,0.05>P>0.01)$.

Thirty three of the 73 virus infections were caused by rhinovirus, which was most often encountered during May and June, and August and September (Fig. 1). The second most frequent virus was respiratory syncytial virus and most of the 14 infections with this occurred during November and December 1982, the time of the only major respiratory syncytial virus outbreak in Oslo during the study period.

The three adeno viruses isolated were all type 2 and of the four strains of parainfluenza virus types 1 , 3 , and 4 were isolated. Of the three isolates of influenza A virus, two were subtype $\mathrm{H} 3 \mathrm{~N} 2$ and one subtype H1N1.

Acute asthmatic attacks among patients with specific aeroallergies. Fig. 2 shows the occurrence of attacks in patients with birch pollen, grass pollen, and $C$ herbarum allergy, and the respective counts of pollens and spores in the atmosphere. No correlation was found between the amount of pollen $/ \mathrm{m}^{3}$ air
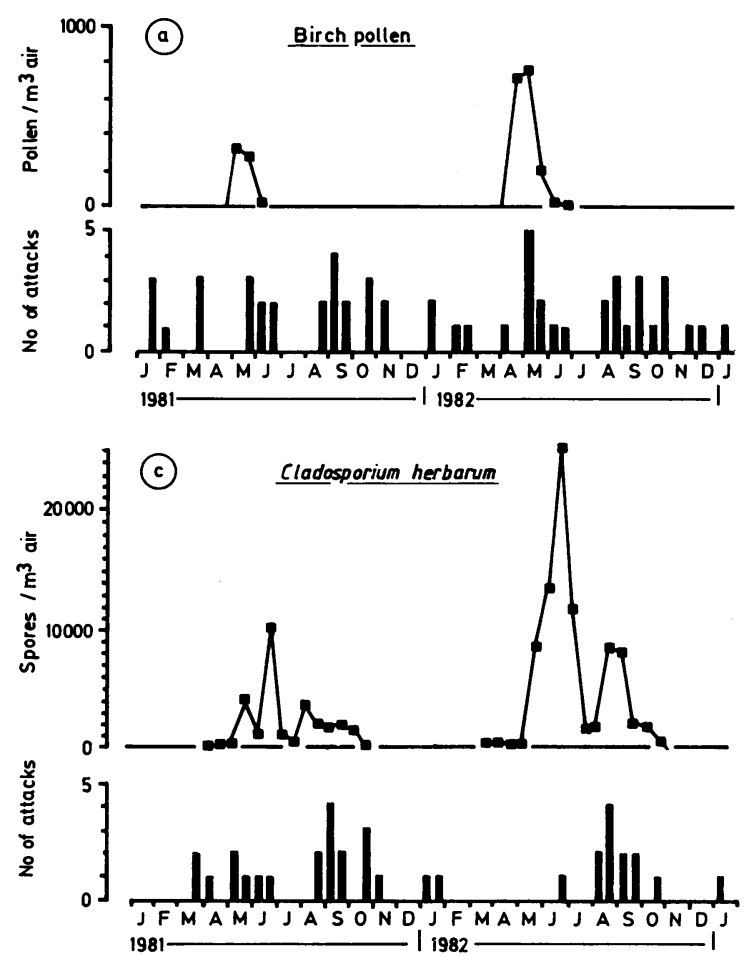

on the first day of symptoms and attacks of acute asthma in patients with birch pollen or grass pollen allergy, nor between spore counts and attacks of asthma in patients with allergy to $C$ herbarum. We found no increased seasonal frequency of attacks for patients with either birch pollen $\left(\chi^{2}=2 \cdot 03\right.$, $P>0 \cdot 1)$, or grass pollen allergy $\left(\chi^{2}=0.75\right.$, $P>0 \cdot 3)$ compared with patients without these allergies. We did find, however, an increased seasonal frequency for patients with cladosporium allergy compared with patients without such allergy $\left(\chi^{2}=6 \cdot 06,0 \cdot 01<\mathrm{P}<0 \cdot 025\right)$.

No correlation was found between the number of asthmatic attacks and weather conditions, measured at the location of the pollen and spore counts, including mean temperatures, total rainfall, and mean barometric pressure/two week period.

Age and sex distribution. The mean age for patients with acute asthma and respiratory virus infection was 5 years 6 monthś and for patients without virus infection 6 years 6 months. The age distribution of the virus infected patients with acute asthma was

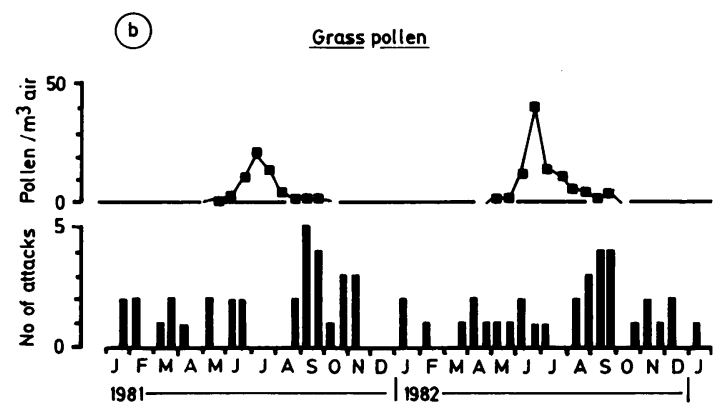

Fig. 2 Counts of birch pollen, grass pollen, and spores of Cladosporium herbarum in the air at Blindern, Oslo (highest value/two week period) and temporal distribution of acute asthmatic attacks/two week period in patients with birch pollen, grass pollen, and Cladosporium herbarum allergy. 
Table Atopy, total IgE, eosinophil counts, and potential pathogenic bacterial findings in nasopharyngeal swabs at presentation in patients with acute asthma with and without respiratory virus infections

\begin{tabular}{|c|c|c|c|c|c|}
\hline & \multirow{2}{*}{$\begin{array}{l}\text { Atopy } \\
\text { No (\%) }\end{array}$} & \multirow{2}{*}{$\begin{array}{l}\text { Mean eosinophil } \\
\text { count }\left(\times 10^{\circ} / l\right)\end{array}$} & \multicolumn{2}{|c|}{ Mean total IgE } & \multirow{2}{*}{$\begin{array}{l}\text { Poisitive bacterial } \\
\text { findings } \\
\text { No }(\%)\end{array}$} \\
\hline & & & RIST U/ml & PRIST kUIl & \\
\hline $\begin{array}{l}\text { With respiratory virus } \\
\text { infection }\end{array}$ & $48(66)$ & $283(n=45)$ & $551(n=19)$ & $345(n=37)$ & $15(21)$ \\
\hline $\begin{array}{l}\text { Without respiratory virus } \\
\text { infection }\end{array}$ & $131(72)$ & $352(n=141)$ & $576(n=67)$ & $489(n=94)$ & $30(17)$ \\
\hline$P$ values & $\chi^{2}=0.84,0.4>P>0.3$ & $\mathrm{P}>0.23^{\circ}$ & $P>0.40^{\circ}$ & $\mathrm{P}>0.15^{\circ}$ & $0.5>P>0.4$ \\
\hline
\end{tabular}

RIST = radioimmunosorbent test PRIST = paper radioimmunosorbent test

"Wilcoxon-Mann-Whitney rank test for two samples.

significantly lower than that of the patients without virus infection ( $\mathrm{W}-\mathrm{M}-\mathrm{W}, \mathrm{P}=\mathbf{0} \cdot 02)$. The age range extended from 2 years to 15 years in both groups. In the virus infected group $29 \%$ were between 2 and 3 years of age, gradually decreasing to one per cent at 15 years of age, whereas in the group without virus infections $24 \%$ were between 2 and 3 years of age, gradually decreasing to one per cent at 15 years of age.

More boys than girls presented with acute asthmatic attacks (boys:girls $=1 \cdot 75$ ). We found no significant difference in sex distribution for children with respiratory virus infection (boys:girls $=1.70$ ) and children without respiratory virus infection (boys:girls $=1.77),\left(\chi^{2}=0.02,0.8<P<0.9\right)$.

Allergy and bacteriological findings. Seventy per cent of all patients with acute asthma were found to be atopic. The Table shows that no difference with regard to atopy was observed between patients with respiratory virus infections and patients without respiratory virus infections $\left(\chi^{2}=0.84\right.$, $0.3<\mathrm{P}<0.4)$. Nor did we find any significant difference between these two groups with regard to mean eosinophil counts on presentation (W-M-W, P>0.23) or total IgE as measured by radioimmunosorbent test (W-M-W, $\mathrm{P}>0.40)$ or paper radioimmunosorbent test (W-M-W, $P>0.15)$ (Table). One hundred and twenty one of the 256 attacks occurred in patients with allergy to animal dander. In 14 of these we obtained information about exposure to animals before symptoms $(12 \%$ of the attacks in patients with animal dander allergy, five per cent of all attacks). The frequency of virus infections among patients with animal dander allergy $(27 \%)$ was not significantly different from the frequency of virus infections among all patients $\left(\chi^{2}=0.17,0.35>P>0.30\right)$.

There was no significant difference between potential pathogenic bacterial findings from nasopharyngeal swabs collected at presentation from patients with and without virus infection $\left(\chi^{2}=0.5\right.$, $0.5>P>0.4$ ), as shown in the Table.

\section{Discussion}

Among the many factors associated with acute asthma our study suggests an important role for respiratory virus infections which occurred in nearly one third of acute attacks. The association between respiratory virus infections and acute asthma has also been noted by others ${ }^{11}$ and in our own previous studies. $^{12}$ The virological results should be interpreted with care as we have no control information from children without asthma in our study. Horn and Yealland, however, found reasons for stating a causal relation between the isolation of a viral agent from the airways during acute respiratory illness. ${ }^{13}$

The positive correlation between acute asthma occurring with and without respiratory virus infection may indicate that even more of the attacks were associated with virus infections. Thus it is possible that more patients were infected by rhinovirus than was detected, as the diagnosis of rhinovirus infection is difficult. We only studied coronavirus infections by a serological method using one human coronavirus as antigen. Recently Isaacs $e t$ al found a high frequency of coronavirus infection when testing upper respiratory tract secretions from children with acute asthma and with recurrent respiratory infections. ${ }^{14}$ Most of their coronaviruses belonged to another antigenic group than that used in our study. That more of the asthmatic attacks may have been associated with respiratory virus infections is also suggested by the similarity of the 'virus infected' and the 'not virus infected' groups with regard to IgE values, frequency of atopy, sex distribution, eosinophilic counts, and bacterial results. Accordingly we found little reason for classifying the asthmatic children by the old terms 'extrinsic' and 'intrinsic' asthma.

The seasonal variation of acute asthma peaked 
during spring and autumn, concurrently with the most frequent detection of rhinovirus infections. Only a few attacks occurred during the summer months, at the time of the year when many children are on holiday. In both years a sharp rise in number of attacks occurred during August and September, at the time of reopening of schools and children's day care centres after summer. This also suggests an important role for infections. All the different respiratory virus groups were associated with acute asthma but this was most pronounced for rhinovirus and respiratory syncytial virus, as has been noted previously. 111215

The frequency of potential pathogenic bacterial findings from nasopharyngeal swabs was not higher among children with asthma than among children without respiratory illness. ${ }^{16}$ We conclude, as did Horn et $a l,{ }^{17}$ that the role of bacterial infections in provoking asthma is probably minor.

The frequency of atopy among our patients with acute asthma was high as was the frequency of positive skin tests found among virus infected asthmatics by Horn et al. ${ }^{11}$ This underlines the central role of reaginic allergy among asthmatic patients. Our findings indicate, however, that birch and grass pollen played only a minor role in acute asthma. Jenkins et al showed similar results in mortality from acute asthma. ${ }^{18}$ Our findings among patients with pollen and animal dander allergy suggest that allergen exposure was a less frequent provoking factor than respiratory virus infections.

On the other hand we found more seasonal asthmatic attacks among patients with cladosporium allergy. Moulds may be more important than poliens in provoking acute asthma in susceptible patients, as was also suggested by the positive correlation between the occurrence of asthma deaths and the counts of hyaline ascospores in the air found by Jenkins et al. ${ }^{18}$ The easier passage of spores through the airways due to their smaller size than pollen may partly explain the difference in occurrence of attacks between patients with cladosporium and pollen allergy. The longer season for cladosporium spores than for pollen and hence the longer exposure may induce late allergic reactions and increase the non-specific bronchial hyperreactivity in these patients, as was proposed by Cockcroft. ${ }^{19}$ This may also explain the increased occurrence of attacks during the last part of the season.

It is probable that several of the above mentioned factors work together in precipitating acute asthma in the individual patient. ${ }^{1}$ In the present study the single most frequent factor associated with acute asthmatic attacks was respiratory virus infection. The study of the epidemiology of respiratory virus infections, the mechanisms of transmission of viral disease, and treatment of viral disease are important fields for research into the prevention of acute asthma in children. As the pathogenicity of respiratory virus infections to cause bronchopulmonary obstruction is becoming better understood ${ }^{20}$ new means of prevention and control of acute asthma may be found.

We thank Målfrid Bru for skilled technical assistance, Magne Fagerhol, for help in analysing the RIST, PRIST and RAST tests and Jan Eng, for help with bacteriological examination. OhioHeLa cells were kindly supplied by the late B Tyler, Salisbury, and the OC 43 strain of human coronavirus by $\mathrm{T}$ Hovi, Helsinki. Financial support has been given by the Norwegian Association against Asthma and Allergy and by Professor Carl Semb's Fund.

\section{References}

${ }^{1}$ Aas K. Heterogeneity of bronchial asthma. Allergy 1981;36: 3-14.

2 Ørstavik I. Susceptibility of continuous lines of monkey kidney cells to influenza and parainfluenza viruses in the presence of trypsin. Acta Pathol Microbiol Scand 1981;89B:179-83.

3 Larson HE, Reed SE, Tyrrell DAJ. Isolation of rhinoviruses and coronaviruses from 38 colds in adults. J Med Virol 1980;5:221-2.

${ }^{4}$ Grist NR, Ross CA, Bell EJ. Diagnostic methods in clinical virology. 2nd ed. Oxford: Blackwell Scientific Publications. 1974.

${ }^{5}$ Voller A, Bidwell DE, Bartlett A. ELISA techniques in virology. In: New developments in practical virology. New York: Alan R. Liss, 1982;59.

${ }^{6}$ Carlsen KH, Ørstavik I. Respiratory syncytial virus infections in Oslo 1972-78. II. Clinical and laboratory studies. Acta Paediatr Scand 1980;69:723-9.

${ }^{7}$ Aas K, Belin L. Standardization of diagnostic work in allergy. First report from the standardization committee of the Northern Society of Allergology 1971. Acta Allergol 1972;27:439-68.

8 Wide L, Bennich H, Johansson SGO. Diagnosis of allergy by an in vitro test for allergen antibodies. Lancet 1967;ii:1105-7.

9 Johansson SGO, Berglund A, Kjellman NIM. Comparison of IgE values as determined by different solid phase radioimmunoassay methods. Clin Allergy 1976;6:91-8.

${ }^{10}$ Hirst JM. An automatic volumetric spore trap. Annals of Applied Biology 1952;39:257-65.

1 Horn MEC, Gregg I. Role of viral infection and host factors in acute episodes of asthma and chronic bronchitis. Chest 1973;63:44.

12 Carlsen KH, Ørstavik I. Bronchopulmonary obstruction in children with respiratory virus infections. Eur $J$ Respir Dis 1984;65:92-8.

13 Horn MEC, Yealland SJ. Significance of respiratory virus isolations. A study in primary school children. Arch Dis Child 1974;49:516-9.

14 Isaacs D, Flowers D, Clarke JR, Valman HB, MacNaughton MR. Epidemiology of coronavirus respiratory infections. Arch Dis Child 1983;58:500-3.

15 McIntosh K. Bronchiolitis and asthma: Possible common pathogenetic pathways. J Allergy Clin Immunol 1976;57: 595-604.

16 Stewart DA, Moghadam H. Are antibiotic drugs needed for the treatment of upper respiratory tract infections in infants? Can Med Assoc J 1972;107:1082-4.

17 Horn MEC, Reed S, Taylor P. Role of viruses and bacteria in acute wheezy bronchitis in childhood; a study of sputum. Arch Dis Child 1979;54:587-92. 
1x Jenkins PF. Mullins J, Davies BH, Williams DA. The possible role of acroallergens in the epidemic of asthma deaths. Clin Allergy 1980;11:611-20.

${ }^{19}$ Cockcroft DW. Mechanism of perennial allergic asthma. Lancet 1983:ii:253-6.

20) Welliver. RC. Wong DT. Sun M, Middleton E, Jr, Vaughan RS, Ogra RL. The development of respiratory syncytial virus- specific $\operatorname{lgE}$ and the release of histamine in nasopharyngeal secretions after infection. $N$ Engl J Med 1981;305:841-6.

Correspondence to Dr K H Carlsen, Department of Paediatrics, Ullevål Hospital, Oslo 1, Norway.

Received 14 January 1984

\section{Personal choice}

\section{Hazardous personal pets ${ }^{1}$}

Salmonella gatuni was isolated from the stools of an 8 month old girl with diarrhoea. Her father keeps lizards and the lizard faeces showed the same bacteria. (Manchester Public Health Laboratory).

Toxocara infection was confirmed in a 5 year old girl whose cat died with definite toxocariasis. (Cardiff Public Health Laboratory).

Streptobacillus moniliformis was isolated from the blood culture of a 43 year old man who had been bitten by his pet rat. (Stoke Public Health Laboratory).

\footnotetext{
${ }^{1}$ Communicable Disease Report 83/47. London: Public Health Laboratory Service, 1983.
} 